\title{
PERANAN WANITA PEDAGANG SAYURAN TERHADAP PENDAPATAN KELUARGA DI PASAR PINASUNGKULAN KAROMBASAN MANADO
}

\author{
Dewanti Rakomole \\ Jenny Baroleh \\ Joachim. N. K. Dumais
}

\begin{abstract}
This study aims to determine the contribution of women vegetable vendors in supporting the family income. This study was carried from July to October 2015 in Pinasungkulan Market Karombasan Manado. Retrieval of data in the form of primary data and secondary data. The primary data obtained through interviews of 10 women vegetable vendors and secondary data obtained from relevant agencies, namely the Department of Market. Data presented in tables and descriptive analysis and to determine the contribution of revenue derived from the percentage of women between revenue wives to the family income. The results showed that women vegetable vendors in the market Pinasungkulan Karombasan have completed elementary school; hovewer most of them do not go on to further education. Woman vegetable merchant who became the object of research is a married woman and still a single. Husband incomes so low that cannot provide for the family to encourage his wife to work together, otherwise it because he wanted to utilize the time available. Women vegetable vendors have to pursue this work between 10 years to 35 years. Working hours of women vegetable vendors are between 8 to 19 hours per day with an average of 13 hours working hours per day. The activities carried out, namely the purchase of vegetables, vegetable cleaning, until the sale of vegetables. Types of vegetables studied were mustard greens (caisin), Chinese cabbage, kale and spinach which is a type of green leafy vegetables commercially. The biggest volume of purchasing / procurement for highland vegetables is mustard greens (caisin) which is an average of 150 bunches per day, and for the type of lowland vegetables are kale that is an average of 160 bunches per day. The average of their husband income was IDR 1.4875 million per month and the average income of wife IDR 2.014 million per month. Wives revenue was greater than husbands' revenue, where the average contribution of wives was $50.01 \%$, which means the wives have played an important role in supporting the family incomes.
\end{abstract}

Keywords : Roles of Women Vegetable Vendors, Family Income, Market, Manado

ABSTRAK
Penelitian ini bertujuan untuk mengetahui besarnya kontribusi wanita pedagang sayuran dalam menunjang pendapatan keluarga. Penelitian ini di laksanakan dari Bulan Juli sampai Bulan Oktober 2015 di Pasar Pinasungkulan Karombasan Manado. Pengambilan data berupa data primer dan data sekunder. Data primer diperolah melalui wawancara pada 10 wanita pedagang sayuran di Pasar Pinangsungkulan dan data sekunder diperoleh dari instansi terkait yaitu Dinas Pasar. Data disajikan dalam bentuk tabel dan analisis secara deskriptif dan untuk mengetahui kontribusi pendapatan wanita diperoleh dari persentase antara pendapatan Istri terhadap pendapatan keluarga. Hasil penelitian menunjukkan bahwa wanita pedagang sayuran di Pasar Pinasungkulan Karombasan pernah mengecap pendidikan SD dan mereka semuanya menamatkan pendidikan mereka; sebagian besar tidak melanjutkan ke jenjang pendidikan selanjutnya. Wanita pedagang sayuran yang menjadi obyek penelitian adalah wanita yang sudah menikah dan masih bersuami. Pendapatan suami yang rendah sehingga tidak dapat mencukupi kebutuhan keluarga mendorong istri untuk turut bekerja, selain itu karena ingin memanfaatkan waktu yang ada. Wanita pedagang sayuran telah menekuni pekerjaan ini antara 10 tahun hingga 35 tahun. Curahan waktu kerja antara 8 hingga 19 jam per hari dengan rata-rata curahan waktu kerja 13 jam per hari. Kegiatan yang dilakukan yaitu pembelian sayur, pembersihan sayur, hingga penjualan sayuran. Jenis sayuran yang diteliti yaitu caisin, petsai, kangkung dan bayam yang merupakan jenis sayuran daun hijau komersial. Volume pembelian/pengadaan untuk jenis sayuran dataran tinggi yang terbesar adalah caisin yaitu rata-rata 150 ikat per hari, dan untuk jenis sayuran dataran rendah adalah kangkung yaitu rata-rata 160 ikat per hari. Rata-rata pendapatan suami Rp. 1.487 .500 per bulan dan rata-rata pendapatan istri Rp. 2.014 .000 per bulan. Pendapatan Istri ternyata lebih besar dari pendapatan suami, dimana kontribusi rata-rata istri sebesar $50,01 \%$ yang artinya istri memegang peranan penting dalam menunjang pendapatan keluarga.

Kata Kunci : Peranan Wanita Pedagang Sayuran, Pendapatan Keluarga, Pasar, Manado 


\section{PENDAHULUAN}

\section{Latar Belakang}

Dewasa ini peran wanita telah semakin terlihat terutama bagi wanita yang sebelumnya mendapat pendidikan yang baik dan mereka ternyata dapat bekerja sejajar dengan pekerja pria serta dengan tingkat pendapatan yang semakin meningkat. Hal ini sangat positif dampaknya dalam konteks pembangunan ekonomi secara keseluruhan dan terutama ekonomi keluarga secara khusus.

Potensi wanita pedagang sayur dapat dilihat dari tingkat intensitas kerjanya (curahan waktu kerja) yang dapat diperinci menurut umur, tingkat pendidikan, upah per bulan, status perkawinan dan tingkat pendapatan keluarga. Kontribusi pedagang sayur wanita dapat dilihat dari proporsi pendapatan pekerja wanita terhadap pendapatan keluarga.

Keluarga merupakan unit terkecil dalam masyarakat yang terdiri dari suami istri atau suami, istri, dan anaknya atau ayah dan anaknya atau ibu dan anaknya (Mongid, 1995).

Oleh karenanya terdapat pembagian kerja antara ayah dan ibu, ayah memiliki areal pekerja publik karena kedudukannya sebagai pencari nafkah utama didalam keluarga, sedangkan ibu memiliki areal pekerja domestik yang dapat diartikan oleh sebagian masyarakat yang menyatakan secara sinis bahwa seorang ibu hanya sekedar wanita yang memiliki tiga fungsi yaitu memasak, melahirkan anak, berhias, atau hanya memiliki tugas dapur, dan kasur (Musrifah, 2009). Dengan demikian seorang suami menjadi kepala keluarga yang memimpin, membimbing, dan melindungi keluarga dari gangguan lahir dan batin, serta mencari nafkah dan keperluan lainnya untuk anak dan istrinya. Mendidik serta dapat menjadi suri teladan bagi anak istrinya merupakan kewajiban seorang kepala keluarga. Begitu juga dengan seorang istri sebagai ibu rumah tangga mempunyai kewajiban membantu suami dalam mempertahankan rumah tangga, mengatur segala keperluan rumah tangga, memperhatikan pendidikan anak, mengatur keuangan sehingga terjadi keselarasan antara pendapatan dan kebutuhan rumah tangga. Untuk mendidik anak, ibu memegang peranan yang paling dominan dibandingkan seorang bapak.

Sesuai dengan anggapan umum masyarakat, seorang wanita atau seorang ibu dianggap tabuh atau menyalahi kodratnya sebagai seorang wanita apabila terlalu sering keluar rumah. Terlebih lagi apabila keluar rumah tanpa memperhatikan alasan mengapa dan untuk apa perbuatan itu dilakukan. Namun jika kita mau melihat dari fakta yang ada di lapangan sering kali wanita menjadi penyelamat perekonomian keluarga. Fakta ini terutama dapat terlihat pada keluarga-keluarga yang perekonomiannya tergolong rendah, banyak dari wanita yang ikut menjadi pencari nafkah tambahan bagi keluarga.

Pada keluarga yang tingkat perekonomiannya kurang atau prasejahtera peran ibu tidak hanya dalam areal pekerja domestik tetapi juga areal publik. Ini dimungkinkan terjadi karena penghasilan ayah sebagai pencari nafkah utama tidak dapat mencukupi kebutuhan keluarga. Para ibu lebih banyak melakukan pekerjaan-pekerjaan yang bersifat informal seperti berdagang, menjadi pembantu rumah tangga dan lain sebagainya dalam upaya mencari nafkah tambahan bagi keluarga.

Keberhasilan suatu keluarga dalam membentuk suatu rumah tangga yang sejahtera tidak lepas dari peran seorang wanita yang begitu besar secara khusus wanita pedagang sayur di pasar. Baik dalam membimbing dan mendidik anak, mendampingi suami, membantu pekerjaan suami bahkan sebagai tulang punggung keluarga dalam mencari nafkah. Namun demikian kebanyakan dari masyarakat masih menempatkan seorang ayah sebagai subyek, sebagai kepala keluarga dan pencari nafkah. Sedangkan ibu lebih ditempatkan sebagai objek yang dinomor duakan dengan kewajiban mengurus anak di rumah.

Pada zaman modern saat ini, seorang wanita atau seorang ibu dituntut untuk kreatif, sabar, ulet dan tekun dalam mencapai kesejahteraan keluarga. Banyak hal yang telah dilakukan ibu sebagai penopang ekonomi keluarga dengan cara berwirausaha, bekerja di perusahaan swasta maupun pemerintah, bahkan menjadi kuli kasar ataupun mengerjakan pekerjaan lainnya yang 
biasa dilakukan oleh laki-laki. Disinilah terlihat bahwa seorang ibu sangat berperan dalam pemberdayaan ekonomi keluarga guna mencapai kesejahteraan keluarga. Ibu dapat berperan ganda disamping tugas pokoknya sebagai pengurus rumah tangga, dan juga membantu perekonomian keluarga, tentu dengan izin suaminya agar tidak menimbulkan konflik dalam rumah tangga. Peran ibu dalam pendidikan anak juga diperlukan untuk mencapai kesejahteraan keluarga. Dengan peran ibu yang dominan dan optimal dalam suatu keluarga yang mencakup tugas pokok seorang ibu sebagai pengurus rumah tangga dan juga perannya dalam perekonomian keluarga, serta dalam pendidikan anak dapat mempengaruhi tingkat kesejahteraan keluarga.

Wanita pedagang sayur ternyata memiliki peran yang penting dalam menyiasati serta mengatasi kemiskinan yang dialaminya. Hal ini adalah salah satu bukti nyata peran wanita dalam menunjang pendapatan keluarga.

\section{Rumusan Masalah}

Berdasarkan latar belakang yang telah dikemukakan, hal yang menjadi rumusan masalah dalam penelitian ini adalah berapa besar kontribusi pendapatan wanita pedagang sayuran dalam menunjang pendapatan keluarga?

\section{Tujuan dan Manfaat Penelitian}

Penelitian ini bertujuan untuk mengetahui kontribusi pendapatan wanita pedagang sayuran dalam menunjang pendapatan keluarga.

Manfaat penelitian ini diharapkan dapat memberikan informasi bagi wanita pedagang sayuran dalam menunjang pendapatan keluarga dan menjadi referensi untuk penelitian selanjutnya.

\section{METODOLOGI PENELITIAN}

Waktu dan Tempat Penelitian

Penelitian ini berlangsung selama 4 bulan yaitu bulan Juli sampai Oktober 2015, dari persiapan sampai penyusunan laporan hasil penelitian. Lokasi penelitian adalah Pasar Pinasungkulan Karombasan Manado.

\section{Metode Pengumpulan Data}

Penelitian ini menggunakan data primer dan data sekunder. Data primer diperoleh melalui wawancara dengan responden berdasarkan daftar pertanyaan yang disiapkan, sedangkan data sekunder diperoleh dari instansi yang terkait dengan penelitian, yaitu Dinas Pasar Pinasungkulan Karombasan Manado serta telaah pustaka.

\section{Metode Pengambilan Sampel}

Populasi dipilih secara sengaja yaitu wanita pedagang sayuran di Pasar Pinasungkulan Karombasan Manado, dengan jumlah populasi 150 0rang. Kemudian dari populasi 150 orang ini dipilih lagi responden yang masih bersuami dan punya tanggungan sebagai sampel. Pengambilan sampel menggunakan metode acak sederhana yaitu dengan mengundi 10 responden dari daftar nama-nama para ibu rumah tangga pedagang sayuran. Dari sekian banyak jenis sayur yang dijual oleh wanita pedagang sayur, dalam penelitian ini hanya dibatasi pada jenis sayuran hijau komersil, yaitu, sawi hijau (caisin), petsai, kangkung dan bayam.

\section{Konsep Pengukuran Variabel}

Adapun variabel-variabel yang akan diamati dan diukur dalam penelitian ini adalah :

1. Karakteristik dari responden seperti umur, tingkat pendidikan, jumlah tanggungan dalam keluarga dan pengalaman usaha. Sayuran yang di didagangkan oleh para responden adalah sayur-sayuran hijau seperti sayur caisin, petsai, kangkung dan bayam.

2. Volume pembelian, yaitu jumlah sayur yang dibeli setiap hari oleh pedagang (ikat).

3. Volume penjualan, yaitu jumlah sayur yang terjual dari setiap kali penjualan per hari (ikat). 
4. Harga, yaitu harga sayur di tingkat penyalur (harga beli wanita pedagang sayur) dan harga di tingkat wanita pedagang sayur (harga jual di tingkat konsumen (Rp/ikat).

5. Pengeluaran adalah semua biaya yang dikeluarkan selama kegiatan berdagang sayur-sayuran seperti biaya pengangkutan/pikul, biaya tenaga kerja, biaya susut/rusak, retribusi pasar dan kebersihan (Rp).

6. Pendapatan Keluarga : pendapatan yang diperoleh suami, istri dan anak (anak-anak) yang dinyatakan dalam rupiah per bulan.

a. Pendapatan suami yaitu pendapatan yang diperoleh dari berbagai pekerjaan yang dijalankan, yang dihitung berdasarkan curahan waktu kerja (Rp/bulan).

b. Pendapatan istri yaitu pendapatan ibu rumah tangga yang didapat dari hasil berdagang sayur yang dihitung berdasarkan curahan waktu (Rp/bulan).

c. Pendapatan anak yaitu pendapatan dari anak pria dan wanita yang belum menikah tapi sudah bekerja (Rp/bulan).

7. Kontribusi adalah : besarnya pendapatan ibu rumah tangga dibandingkan dengan dengan total pendapatan keluarga yang dinyatakan dalam persentase.

8. Curahan waktu kerja : lama waktu yang diperlukan oleh suami dan istri selama proses berdagang yang dinyatakan dalam jam per hari.

\section{Metode Analisis Data}

Sesuai dengan permasalahan dan tujuan yang ingin dicapai, maka analisis data yang digunakan adalah analisis secara deskriptif kualitatif dan disajikan dalam bentuk tabel.Untuk menghitung pendapatan wanita pedagang sayur, digunakan rumus :

$$
\mathbf{I}=\mathbf{T R}-\mathbf{T C}
$$

Dimana $: \mathrm{I} \quad=$ Pendapatan wanita pedagang sayur

$\mathrm{TR}=$ Total penerimaan wanita pedagang sayur

$\mathrm{TC}=$ Total biaya yang dikeluarkan oleh wanita pedagang sayur
Untuk menghitung kontribusi wanita pedagang sayur, digunakan rumus :

Kontribusi wanita pedagang sayur $=\frac{\text { Pendapatan } \text { wanita pedagang sayur }}{\text { Total pendapatan } \text { keluarga }} \times 100 \%$

\section{HASIL DAN PEMBAHASAN}

\section{Deskripsi Wilayah Penelitian}

Pasar Pinasungkulan merupakan salah satu pusat perbelanjaan yang ada di Kota Manado, yang terletak di bagian ujung selatan Kecamatan Sario. Kedudukan pasar berada di Kelurahan Karombasan yang berhadapan dengan kompleks pertokoan Pinasungkulan Plaza. Adapun batas-batas dari pasar Pinasungkulan adalah sebagai berikut :

Sebelah utara berbatasan dengan kelurahan Pakowa

Sebelah selatan berbatasan dengan kelurahan Karombasan

Sebelah barat berbatasan dengan kelurahan Ranotana Weru.

Jalan masuk yang menghubungkan pasar Pinasungkulan adalah jalur aspal yang dapat dilalui oleh beberapa kendaraan jenis angkutan kota dari beberapa wilayah kota Manado, bahkan di sekitar lokasi pasar terdapat terminal kendaraan jenis angkutan luar kota. Dengan kondisi ini, menjadikan pasar Pinasungkulan merupakan salah satu pasar yang ramai di kota Manado karena banyak dikunjungi pembeli baik yang ada di sekitar lokasi pasar maupun yang jauh dari lokasi pasar pasar dan merupakan tempat pertemuan pedagang-pedagang dari berbagai daerah Minahasa bahkan juga di luar daerah Minahasa seperti Kotamobagu dan Gorontalo. Sarana angkutan digunakan oleh para konsumen untuk datang berbelanja umumnya adalah angkutan kota dan bendi, sedangkan sarana angkutan yang digunakan oleh produsen untuk mengangkut hasil komoditi sayur-sayuran pick up.Wanita pedagang sayur yang ada di pasar Pinasungkulan Karombasan terdiri dari berbagai latar belakang suku, seperti Minahasa dan Gorontalo. Tempat berjualan dari masingmasing wanita pedagang sayur berbeda-beda, ada yang berupa tenda dengan beratap seng dan ada yang hanya menggunakan terpal sebagai 
pengaman untuk menghindari sengatan matahari ataupun terpaan hujan. Begitu pula tempat yang digunakan oleh pedagang wanita untuk meletakkan sayur-sayuran yang dijual berbeda-beda, ada yang diletakkan di atas meja dan ada yang hanya menggunakan alas tikar ataupun terpal. Kegiatan di pasar Pinasungkulan berlangsung setiap hari dimulai pada jam 04.00 pagi sampai jam 21.00. Paling ramai konsumen datang berbelanja di pasar ini sekitar jam 07.00 sampai jam 11.00 dan mulai sepi pada jam 12.00 sampai jam 15.00. Kegiatan jual beli mulai ramai lagi sekitar jam 16.00 sampai jam 20.00. Kegiatan jual beli di pasar Pinasungkulan rata-rata berhenti pada jam 21.00.

Sesuai data dari Dinas Pasar Pinasungkulan Karombasan, luas pasar yaitu 2 Ha, dengan banyaknya kios permanen 170 buah, bak-bak penjualan bantuan Inpres 63 buah, tenda-tenda/pelataran sebanyak 700 buah dan jumlah pedagang yang berjualan bervariasi antara 1350 sampai 1500 pedagang. Khusus untuk wanita pedagang sayur berjumlah 100 pedagang. Khusus untuk sayuran hijau, secara umum dapat dikatakan bahwa daya serap (daya beli) wanita pedagang sayur di pasar Pinasungkulan Karombasan setiap harinya yaitu Caisin 1350 ikat, petsai 178 ikat, kangkung 1600 ikat dan bayam 715 ikat. Dari jumlah tersebut, yang dapat dijual ke konsumen akhir (daya serap/daya beli konsumen terhadap sayuran hijau yang dijual di pasar Pinasungkulan Karombasan) yaitu caisin 1292 ikat, petsai 158, kangkung 1600 ikat dan bayam 700 ikat. Sayuran yang diperdagangkan di pasar Pinasungkulan berasal dari Modoinding, Tomohon, Tondano dan Tateli.

\section{Karakteristik Pasar Pinasungkulan Karombasan Manado}

Pasar Pinasungkulan merupakan bentuk pasar persaingan sempurna, yaitu suatu pasar yang terdapat pembeli dan penjual dalam jumlah yang sangat banyak. Menurut Sudarso (1992), bentuk pasar persaingan sempurna mempunyai sifat-sifat : jumlah pembeli dan penjual sangat banyak, barang yang dipasarkan merupakan barang homogen, artinya jenis barang yang ditawarkan semua penjual tidak dapat dibedakan satu dengan yang lain, penjual dan pembeli secara perorangan tidak dapat mempengaruhi harga pasar, keluar masuk pasar bagi penjual dan pembeli adalah bebas, penjual dan pembeli memiliki informasi pasar (harga) yang lengkap.

\section{Umur Responden \\ Karakteristik Responden}

Umur para pedagang sayur di daerah penelitian bervariasi antara 33 hingga 50 tahun ke atas untuk jenis pekerjaan yang sama yaitu pedagang sayuran. Kemampuan responden untuk melakukan pekerjaan ini di tentukan oleh faktor umur. Pada umumnya orang yang berumur muda dan sehat mempunyai kemampuan fisik yang lebih besar dibandingkan dengan orang yang berumur tua. Tabel 1 akan memperlihatkan variasi umur responden.

Tabel 1. Responden Menurut Kelompok Umur

\begin{tabular}{cccc}
\hline No. & Umur (Tahun) & $\begin{array}{c}\text { Respon- } \\
\text { den } \\
\text { (Orang) }\end{array}$ & $\begin{array}{c}\text { Persen- } \\
\text { tase }(\%)\end{array}$ \\
\hline 1. & $33-38$ & 1 & 10 \\
2. & $>38-43$ & 4 & 40 \\
3. & $>43-48$ & 1 & 10 \\
4. & $>48-53$ & 4 & 40 \\
\hline & Jumlah & 10 & 100 \\
\hline
\end{tabular}

Sumber : Data Primer, 2015 (diolah)

Tabel 1 memperlihatkan bahwa responden yang berusia 33 tahun sampai dengan 38 tahun berjumlah 10\%, 38 tahun sampai dengan 43 tahun berjumlah 40\%, 43 tahun sampai dengan 48 tahun berjumlah $10 \%$ dan responden yang berusia 48 tahun sampai dengan 53 tahun berjumlah $40 \%$.

Dari penelitian ini dapat diketahui bahwa wanita pedagang sayuran yang berdagang di pasar Pinasungkulan Karombasan di dominasi oleh ibu-ibu yang telah berusia 50 tahun ke atas dan bahkan tidak jarang terlihat mereka adalah telah berusia lanjut namun tetap melakukan aktivitas setiap hari sebagai pedagang sayur.

\section{Pendidikan Responden}

Pendidikan memegang peranan penting dalam usaha menciptakan perubahan-perubahan 
dalam kehidupan masyarakat. Salah satunya adalah perubahan cara berpikir masyarakat untuk meningkatkan pendapatan keluarga. Semakin tinggi pendidikan diharapkan pola pikir penduduk semakin rasional. Tinggi rendahnya tingkat pendidikan responden dapat dilihat pada Tabel 2. Tabel 2 menjelaskan bahwa 30\% responden berstatus pendidikan terakhir tamatan Sekolah Dasar (SD), 60\% responden berstatus pendidikan terakhir tamatan SMP, 10\% responden berstatus pendidikan terakhir SMA, dari keseluruhan responden tidak ada yang berstatus pendidikan sarjana. Dari penelitian ini dapat diketahui bahwa untuk menjadi pedagang sayuran di pasar Pinasungkulan Karombasan tidak memerlukan pendidikan yang tinggi hanya membutuhkan pengalaman untuk bisa berinteraksi dan menjual segala dagangan dengan baik.

\section{Tabel 3. Jumlah Tanggungan Wanita Pedagang Sayuran Di Pasar Pinasungkulan Manado}

No. Jumlah Tanggungan (Anak)
Jumlah

Responden
Persentase (\%)

20

40

40

3.

$$
1-2
$$

4

4

100

Sumber : Data Primer, 2015 (diolah)

\section{Jumlah Tanggungan Keluarga}

Jumlah tanggungan keluarga mempengaruhi pendapatan per kapita. Makin banyak tanggungan suatu keluarga makin besar biaya yang harus dikeluarkan, makin sedikit tanggungan keluarga makin sedikit juga biaya yang dikeluarkan. Tanggungan keluarga merupakan salah satu alasan utama bagi para ibu rumah tangga turut serta dalam membantu suami untuk memutuskan diri untuk bekerja untuk memperoleh penghasilan. Banyaknya anak dalam keluarga dapat dilihat pada Tabel 3. Jumlah tanggungan merupakan banyaknya orang yang dibiayai dalam suatu rumah tangga. Dari tabel di atas dapat dilihat bahwa $40 \%$ dari responden mempunyai tanggungan keluarga rata-rata 1 orang sampai dengan 2 orang, $\quad 40 \%$ responden mempunyai tanggungan keluarga rata-rata 3 orang sampai dengan 4 orang, dan responden yang tidak mempunyai tanggungan keluarga hanya $20 \%$.

Hal ini menunjukkan bahwa makin besarnya kesadaran responden untuk mengatur jumlah anak. Mereka menyadari makin banyak anak, maka banyak pula biaya untuk memenuhi kebutuhan hidup keluarga.

\begin{tabular}{|c|c|c|c|}
\hline Tabe & $\begin{array}{l}\text { Tingk } \\
\text { Pedag }\end{array}$ & $\begin{array}{l}\text { Pendidika } \\
\text { Sayuran }\end{array}$ & Wanita \\
\hline No. & $\begin{array}{c}\text { Tingkat } \\
\text { Pendidikan }\end{array}$ & $\begin{array}{l}\text { Responden } \\
\text { (Orang) }\end{array}$ & $\begin{array}{l}\text { Persentase } \\
(\%)\end{array}$ \\
\hline 1. & SD & 3 & 30 \\
\hline 2. & SLTP & 6 & 60 \\
\hline 3. & SMU & 1 & 10 \\
\hline & Jumlah & 10 & 100 \\
\hline
\end{tabular}

Sumber : Data Primer, 2015 (diolah) 


\section{Pengalaman Usaha}

Pada umumnya responden sudah cukup lama bekerja sebagai pedagang sayuran, hal ini dapat dilihat pada Tabel 4. Berdasarkan data yang tersaji pada Tabel 4 , sebanyak $40 \%$ responden telah menekuni pekerjaan ini dalam kurun waktu 10 hingga 18,3 tahun. Responden yang menekuninya selama 18,3 hingga 26,6 tahun tercatat $20 \%$ dan responden yang menekuni pekerjaan selama 26,6 hingga 35 tahun sebanyak 40\%. Dengan adanya pengalaman berusaha ini maka akan mempermudah responden untuk mengambil keputusan yang berhubungan dengan usaha pemasaran sayur, dalam hal ini pengambilan keputusan untuk menentukan jenis, kualitas, jumlah sayur yang akan dibeli, menentukan tempat pembelian sayur serta lokasi penjualan sayur tersebut.

\begin{tabular}{|c|c|c|c|}
\hline & $\begin{array}{l}\text { pedag } \\
\text { Pinası } \\
\text { Mana }\end{array}$ & $\begin{array}{l}\text { ng sayur v } \\
\text { ngkulan } \\
\text { o }\end{array}$ & $\begin{array}{l}\text { nita Di Pasar } \\
\text { Karombasan }\end{array}$ \\
\hline No. & $\begin{array}{l}\text { Lama } \\
\text { Usaha } \\
\text { (Tahun) }\end{array}$ & $\begin{array}{c}\text { Jumlah } \\
\text { Responden }\end{array}$ & $\begin{array}{c}\text { Persentase } \\
(\%)\end{array}$ \\
\hline 1. & $10-18,3$ & 4 & 40 \\
\hline 2. & $\begin{array}{c}>18,3- \\
26,6\end{array}$ & 2 & 20 \\
\hline \multirow[t]{2}{*}{3.} & $\begin{array}{c}>26,6- \\
35\end{array}$ & 4 & 40 \\
\hline & Jumlah & 10 & 100 \\
\hline
\end{tabular}

Sumber : Data Primer, 2015 (diolah)

\section{Deskripsi Usaha}

Pekerjaan di sektor informal pola kegiatannya tidak teratur baik dalam waktu ke waktu, permodalan maupun penerimaan (Oey-Gardiner, 1996), dalam arti usaha ini usaha ini tergolong relatif kecil dan tidak stabil. Sektor informal membuka kesempatan kerja bagi masyarakat dengan tingkat pendidikan yang rendah. Meskipun pendapatan di sektor ini tidak tetap tapi lebih lentur karena bisa diatur paro waktu atau penuh, atau kalau perlu dihentikan sama sekali (Ihromi, 1995). Jika tugas dalam rumah tangga harus diutamakan, dengan demikian pekerjaan di sektor ini bisa ditunda atau bahkan dihentikan kegiatannya.

Mendagangkan sayuran hijau di jadikan mata pencaharian oleh ibu rumah tangga yang berjualan sayuran hijau di pasar Pinasungkulan Karombasan guna perbaikan ekonomi rumah tangga. Sayuran yang dipasarkan terdiri atas sayur caisin, petsai, kangkung dan bayam.

\section{Kapasitas Sayuran Daun di Tingkat Wanita Pedagang Sayuran}

Kegiatan menjual tidak dapat berhasil dengan baik bila tanpa didasari oleh kebijaksanaan dalam pembelian secara tepat, karena pembelian yang dilakukan baik jumlahnya, waktunya, macamnya, dan sebagainya akan dapat mempengaruhi tingkat keuntungan, kelancaran, penjualan dan sebagainya dari setiap produsen maupun pedagang.

Sayur-sayuran yang dijual oleh pedagang wanita dibeli dari pedagang pengumpul yang memasarkan dagangannya di pasar Pinasungkulan, dan mereka tidak melakukan pembelian langsung kepada petani di pasar daerah produksi mengingat besarnya pengangkutan yang harus dikeluarkan. Kecuali pada saat itu jumlah sayur yang masuk sangat sedikit dan para pedagang wanita tidak memperolah sayur-sayuran untuk dijual, maka mereka harus membeli sayursayuran tersebut langsung kepada petani di pasar produksi (Tomohon).

Sayur-sayuran yang dibeli oleh pedagang wanita dari pedagang pengumpul ada yang dibayar secara kontan dan ada yang secara kredit. Hasil penelitian menunjukkan bahwa cara pembelian dengan kontan yang paling banyak dilakukan oleh para pedagang wanita, yakni sebesar 90\% atau 7 responden. Sedangkan yang membeli secara kredit sebesar $10 \%$ atau 3 responden. Pembelian secara kredit ini artinya sayur yang dibeli akan dilunasi pembayarannya setelah sayur tersebut laku dijual. Dalam pembayaran secara kredit ini faktor kepercayaan dan kejujuran sangat penting. 
Volume pembelian dan volume penjualan sayuran hijau ditingkat pedagang wanita dapat dilihat pada Tabel 5.

Pada Tabel 5 dapat dilihat bahwa volume pembelian rata-rata dari masingmasing sayuran untuk dijual ke konsumen akhir berbeda-beda. Perbedaan dalam volume pembelian ini dipengaruhi oleh tingkat harga beli dari masing-masing sayuran. Makin rendah harga sayur, makin banyak volume pembelian/pengadaan sayur tersebut. Untuk jenis sayuran dataran tinggi, volume pembelian/pengadaan sayur caisin lebih besar dari sayur petsai. Hal ini disebabkan harga beli dari sayur caisin lebih murah dibanding dengan sayur petsai, yaitu Rp. 1.500/ikat, sedangkan petsai sebesar Rp. 5.000/ikat. Untuk jenis sayuran dataran rendah, volume pembelian/pengadaan sayur kangkung jauh lebih besar daripada volume pembelian/pengadaan sayur bayam. Hal ini disebabkan harga beli dari sayur kangkung jauh lebih murah dibanding dengan harga sayur bayam, yaitu Rp. 2.000/ikat sedangkan harga beli bayam sebesar Rp. 5.000/ikat. Selain karena pengaruh perbedaan harga tersebut, besarnya pengadaan sayur kangkung juga disebabkan karena pasokan kangkung ke pasar Pinasungkulan Karombasan cukup banyak, yaitu dipasok langsung dari dua daerah produksi kangkung yakni Tondano dan Tateli. Sedangkan bayam hanya dipasok dari Tomohon.

Dari rata-rata pengadaan sayuran hijau tersebut, tidak semuanya dapat terjual karena sebagian dari sayur-sayuran tersebut mengalami kerusakan/susut selama penjualan, sehubungan dengan sifatnya yang mudah rusak dan tidak dapat disimpan lama.

\section{Tingkat Kerusakan Sayuran}

Sayur-sayuran merupakan salah satu komoditi pertanian yang tidak dapat disimpan lama/mudah rusak. Selama sayur-sayuran tersebut berada di tangan pedagang wanita (dalam arti belum terjual), selama itu pula pedagang wanita harus menanggung resiko kerusakan sebagai konsekuensi pemilik barang terakhir sebelum dijual kepada konsumen, yang berarti pula produsen (petani) maupun penyalur tidak terikat lagi dengan resiko tersebut.Hubungan antara tingkat kerusakan sayuran hijau dengan biaya pada tingkat pedagang wanita dapat dilihat pada tabel berikut

Tabel 5. Volume Pembelian Dan Volume Penjualan Rata-rata Sayuran Ditingkat Pedagang Wanita

\begin{tabular}{llccc}
\hline No. & Jenis Sayur & $\begin{array}{c}\text { Volume } \\
\text { Pembelian Rata- } \\
\text { rata (Ikat/Hari) }\end{array}$ & $\begin{array}{c}\text { Volume Penjualan Rata-rata } \\
\text { (Ikat/Hari) }\end{array}$ & Sisa (Ikat/Hari) \\
\hline 1. & Caisin & 150 & 137,2 & 11,7 \\
2. & Petsai & 19,7 & 17,3 & 2,1 \\
3. & Kangkung & 160 & 147,9 & 7,7 \\
4. & Bayam & 27,7 & 24,3 & 1,8 \\
\hline
\end{tabular}

Sumber : Data Primer, 2015 (diolah)

Tabel 6. Hubungan tingkat penyusutan/kerusakan sayuran dengan biaya pada tingkat wanita pedagang sayur

\begin{tabular}{lcc}
\hline Jenis sayuran & $\begin{array}{c}\text { Tingkat Penyusutan/kerusakan } \\
\text { rata-rata (ikat) }\end{array}$ & $\begin{array}{c}\text { Nilai/Biaya } \\
\text { Penyusutan/Kerusakan } \\
(\mathrm{Rp})\end{array}$ \\
\hline Caisin & & 18.166 \\
Petsai & 12,1 & 12.222 \\
Kangkung & 2,4 & 24.200 \\
Bayam & 12,1 & 17.222
\end{tabular}

Sumber : Data Primer, 2015 (diolah) 
Tingkat kerusakan sayuran hijau pada tingkat wanita pedagang sayur terdiri dari : (1) tingkat kerusakan pada tahap pembersihan, yaitu bagian yang dikeluarkan/dibuang pada tahap pembersihan dari krop/daun/batang yang sudah tua atau rusak untuk siap dijual ke konsumen akhir, (2) tingkat kerusakan/susut yang didapat dari besarnya kerusakan sayur caisin, petsai, kangkung dan bayam selama

sayur-sayuran tersebut berada di tangan pedagang wanita/saat penyimpanan.

Tabel 6 menunjukkan bahwa nilai/biaya kerusakan untuk masing-masing sayuran berbeda-beda. Untuk jenis sayuran hijau dataran tinggi, biaya kerusakan terbesar adalah caisin yaitu rata-rata Rp. 18.166 untuk jumlah pembelian rata-rata 150 ikat. Hal ini disebabkan tingkat kerusakan sayur caisin lebih besar dari tingkat kerusakan sayur petsai yaitu sebesar 12,1 persen dari rata-rata pembelian sayur

caisin. Besarnya tingkat kerusakan ini juga disebabkan karena caisin adalah sayuran yang sifatnya lebih mudah rusak dan tidak tahan lama dibanding dengan petsai. Dimana dari hasil penelitian diperoleh data bahwa sayur caisin

hanya dapat bertahan selama 2 hari sejak berada di tangan wanita pedagang sayur, sedangkan petsai dapat bertahan/disimpan sampai 3 hari.

Untuk jenis sayuran hijau dataran rendah, biaya kerusakan yang terbesar adalah kangkung yaitu rata-rata Rp. 24.200 untuk jumlah pembelian rata-rata 160 ikat. Dibanding dengan bayam, kangkung lebih mudah rusak dan tidak dapat disimpan lebih lama karena hanya dapat disimpan selama 2 hari sejak berada di tangan wanita pedagang sayur, sedangkan bayam dapat disimpan sampai 3 hari asalkan selama penyimpanan diberi perlakuan yang baik/benar sesui dengan sifat bayam tersebut.

Dari lampiran 2-5 dapat dilihat bahwa semakin besar jumlah pengadaan sayur oleh wanita pedagang sayur, semakin besar pula tingkat kerusakan sayur tersebut dan berarti pula semakin besar biaya kerusakan yang di tanggung oleh wanita pedagang sayur.
Demikian juga semakin lama sayur-sayuran tersebut berada di tangan pedagang wanita, makin besar biaya yang ditanggung akibat dari kerusakan yang terjadi dan menyebabkan makin kecil bagian yang diterima wanita pedagang sayur.

Besarnya kerusakan sayur-sayuran tersebut, dipengaruhi juga oleh keadaan tempat penyimpanan dari sayur-sayuran tersebut. Umumnya para pedagang wanita tidak memiliki sarana yang baik untuk menyimpan dagangannya apabila belum terjual. Sayursayuran tersebut biasanya disimpan dalam wadah-wadah yang sederhana dan dalam keadaan kotor, sehingga menyebabkan sayuran lekas rusak.

Adapun tanggapan/pandangan responden mengenai resiko ini yaitu sebanyak 43,3 persen memperhitungkan resiko tersebut pada harga jual dan selebihnya 56,7 persen tidak memperhitungkan resiko tersebut, dalam arti resiko itu sangat kecil dan tidak berarti karena kerugian akibat resiko kerusakan ini masih dapat ditutupi oleh penjualan sayuran lain (sayuran yang tahan simpan).

\section{Biaya Pengeluaran}

Pengeluaran adalah semua biaya yang dikeluarkan selama kegiatan berdagang sayursayuran seperti biaya pengangkutan/pikul, biaya tenaga kerja, biaya resiko, retribusi pasar dan biaya kebersihan seperti terlihat pada Tabel 7 .

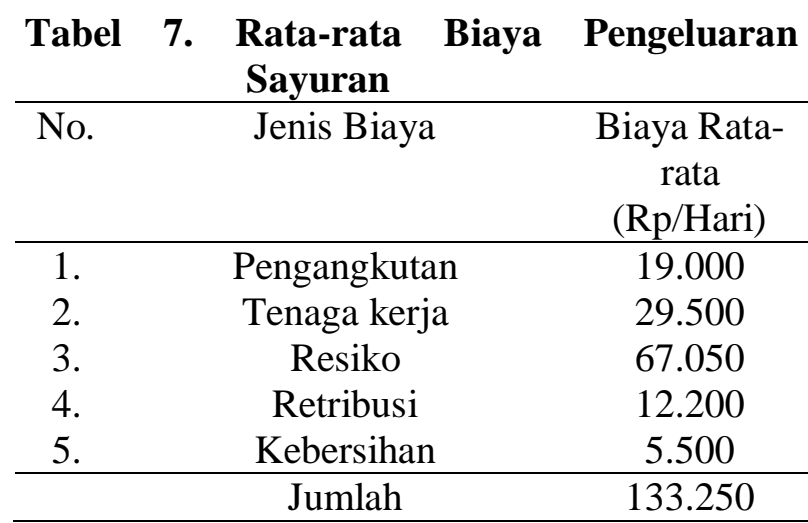

Sumber : Data Primer, 2015 (diolah)

Dari Tabel 7 dapat dilihat bahwa biaya rata-rata yang dikeluarkan oleh wanita pedagang sayur dalam pemasaran sayuran hijau yaitu sebesar Rp. 133.250 per hari. Dari jumlah tersebut, biaya resiko/susut adalah biaya yang 
terbesar yaitu sebesar Rp. 67.050. Sedangkan biaya yang terkecil adalah biaya kebersihan yaitu Rp. 5.500.

Dalam penelitian ini, yang dimaksud dengan biaya pengangkutan yaitu biaya yang di keluarkan oleh setiap wanita pedagang sayur untuk mengangkut sayur-sayuran dari tempat pembelian ke tempat penjualan.

Biaya resiko/susut adalah biaya yang dikeluarkan akibat berkurangnya berat atas volume dari sayuran yang dipasarkan, baik itu terjadi karena pengupasan (waste) maupun karena kerusakan saat penyimpanan. Besarnya kerusakan untuk setiap jenis sayuran diukur per ikat, kemudian dikalikan dengan harga beli dari masing-masing sayuran untuk mendapatkan nilai uang.

Biaya tenaga kerja adalah biaya yang dikeluarkan untuk membayar tenaga kerja. Biaya ini diukur berdasarkan tingkat upah yang berlaku yaitu Rp. 25.000 - Rp. 35.000 per orang per hari. Dalam penelitian ini, responden yang menggunakan tenaga kerja luar keluarga maupun tenaga kerja dalam keluarga dimasukan dalam perhitungan upah yang dikeluarkan.

Retribusi dan biaya kebersihan adalah sejumlah uang yang dipungut oleh pemerintah atas penjualan sayur-sayuran dari pedagang wanita.

Besarnya pajak dan biaya kebersihan tergantung dari besarnya lokasi/tempat penjualan, dengan patokan : ukuran lokasi penjualan sebesar $1 \mathrm{x} 1$ m dikenakan pajak sebesar Rp. 10.000 sampai Rp. 20.000 dan biaya kebersihan sebesar Rp. 5.000 - Rp. 8.000.

Untuk mendapatkan biaya pemasaran pada masing-masing jenis sayuran, maka biayabiaya tersebut diatas dikenakan pada setiap jenis sayuran yang dijual oleh wanita pedagang sayur.

\section{Harga}

Hanafiah dan Saefudin (1983) menyatakan bahwa harga suatu barang adalah nilai pasar (nilai tukar) dari barang tersebut yang dinyatakan dalam jumlah uang. Adapun tingkat harga rata-rata dari masing-masing sayuran dapat dilihat pada Tabel 8 berikut ini :
Tabel 8. Tingkat Harga Rata-rata Dari
Masing-masing Sayuran

\begin{tabular}{clcc}
\hline No. & Jenis Sayur & $\begin{array}{c}\text { Harga Beli } \\
\text { (Rp/Ikat) }\end{array}$ & $\begin{array}{c}\text { Harga Jual } \\
\text { (Rp/Ikat) }\end{array}$ \\
\hline 1. & Caisin & 1.500 & 3.000 \\
2. & Petsai & 5.000 & 7.000 \\
3. & Kangkung & 2.000 & 3.500 \\
4. & Bayam & 5.000 & 7.000 \\
\hline
\end{tabular}

Sumber : Data Primer, 2015 (diolah)

Biasanya yang terjadi di lokasi penelitian, pada setiap hari senin harga sayursayuran sedikit lebih mahal dibanding dengan hari-hari lainnya. Karena pada hari senin jumlah sayur-sayuran yang dijual oleh para pedagang wanita lebih sedikit sebab pasokan sayur-sayuran dari penyalur/pedagang pengumpul pada hari tersebut kurang.

Pekerjaan ini memakan banyak waktu sehingga responden memerlukan bantuan dalam proses penjualan sayuran. Tabel 9 akan memperlihatkan jumlah responden yang menyewa tenaga kerja luar keluarga dan yang tidak menyewa tenaga kerja.

\section{Penggunaan Tenaga Kerja}

Mengingat pekerjaan ini membutuhkan waktu kerja yang cukup panjang dan membutuhkan kemampuan fisik yang besar, maka penggunaan tenaga kerja sangat diperlukan untuk membantu kegiatan usaha para wanita pedagang sayur.

Tabel 9. Penggunaan Tenaga Kerja Wanita Pedagang Sayur Di Pasar Pinasungkulan Karombasan Manado

\begin{tabular}{clcc}
\hline No. & $\begin{array}{l}\text { Penggunaan } \\
\text { Tenaga }\end{array}$ & $\begin{array}{c}\text { Jumlah } \\
\text { Responden } \\
\text { Kerja }\end{array}$ & $\begin{array}{c}\text { Persentase } \\
(\%)\end{array}$ \\
\hline 1. & Suami & 5 & 50 \\
2. & Anak & 2 & 20 \\
3. & Luar & 3 & 30 \\
& keluarga & & 100
\end{tabular}

Sumber : Data Primer, 2015 (diolah)

Berdasarkan hasil penelitian $100 \%$ dari keseluruhan wanita pedagang sayur menggunakan tenaga kerja tambahan untuk 
membantu usaha mereka, baik itu tenaga kerja dari dalam keluarga maupun dari luar keluarga, jumlah tenaga kerja yang digunakan berkisar 1 samapi 2 orang dengan upah yang diberikan berkisar Rp.25.000 - Rp.35.000 per hari.

Tabel 10 akan menjelaskan banyaknya suami yang terlibat dalam proses pemasaran.

Tabel 10. Jumlah Responden Yang Suaminya Terlibat Dalam Proses Penjualan Sayuran

\begin{tabular}{clcc}
\hline No. & Responden & $\begin{array}{c}\text { Jumlah } \\
\text { (Orang) }\end{array}$ & $\begin{array}{c}\text { Persen- } \\
\text { tase }(\%)\end{array}$ \\
\hline 1. & $\begin{array}{l}\text { Suami yang } \\
\text { membantu }\end{array}$ & 5 & 50 \\
2. & $\begin{array}{l}\text { Suami tidak } \\
\text { membantu }\end{array}$ & 5 & 50 \\
\hline & Jumlah & 10 & 100 \\
\hline
\end{tabular}

Sumber : Data Primer, 2015 (diolah)

Tabel 10 menunjukkan sebagian besar suami atau sebanyak 50\% ikut terlibat dalam proses pengangkutan/pikul baik itu membeli sayuran atau proses pembersihan sayuran. Dalam penelitian ini yang dilihat hanya suami yang membantu selama proses membeli sayuran, bukannya yang turut membantu selama proses pemasaran sayuran. Sebanyak $50 \%$ lainnya tidak dibantu suami, dikarenakan suaminya bekerja sebagai buruh bangunan, buruh tani, pegawai negeri, dan wiraswasta.

\section{Peranan Wanita Pedagang Sayuran Curahan Waktu Kerja}

Pekerjaan sebagai pedagang sayuran memakan waktu lebih banyak dari pada jam kerja di sektor formal, hari kerjanya pun tidak beraturan. Tabel 11 dan 12 berikut akan menjelaskan banyaknya waktu yang dibutuhkan untuk proses pemasaran.

Tabel 11 menunjukkan responden mempunyai jam kerja minimal 8 jam sehari. Data di atas memperlihatkan penggunaan waktu yang sangat besar, dimana sebanyak $40 \%$ menghabiskan lebih dari separuh waktu dalam sehari. Bahkan 30\% mencurahkan waktu lebih dari 15 jam sehari. Responden mengatakan sedikit waktu yang bisa mereka pakai untuk beristirahat dan melakukan kegiatan lain. Termasuk terbatasnya alokasi waktu yang dicurahkan untuk kegiatan rumah tangga. Karena itu responden memerlukan bantuan suami dalam proses pemasaran. Kebanyakan responden tidak berjualan penuh dalam seminggu, ada hari yang mereka sediakan untuk pekerjaan lain misalnya melakukan pekerjaan rumah tangga, ke kebun dan beristirahat. Tabel 12 akan memperlihatkan curahan waktu kerja suami selama membantu istri dalam proses pemasaran.

Tabel 11. Curahan Waktu Kerja Responden Sebagai Pedagang Sayuran

\begin{tabular}{|c|c|c|c|}
\hline No. & $\begin{array}{c}\text { Waktu } \\
\text { Kerja } \\
\text { (Jam/Hari) }\end{array}$ & $\begin{array}{c}\text { Jumlah } \\
\text { Responden }\end{array}$ & $\begin{array}{c}\text { Persentase } \\
(\%)\end{array}$ \\
\hline 1. & $8-11,6$ & 3 & 30 \\
\hline 2. & $\begin{array}{l}>11,6- \\
15,2\end{array}$ & 4 & 40 \\
\hline 3. & $>15,2-19$ & 3 & 30 \\
\hline & Jumlah & 10 & 100 \\
\hline
\end{tabular}

Sumber : Data Primer, 2015 (diolah)

Tabel 12. Curahan Waktu Kerja Suami Dalam Proses Penjualan Sayuran

\begin{tabular}{ccc}
\hline $\begin{array}{c}\text { Waktu } \\
\text { (Jam/Hari) }\end{array}$ & $\begin{array}{c}\text { Jumlah } \\
\text { (Orang) }\end{array}$ & $\begin{array}{c}\text { Persentase } \\
(\%)\end{array}$ \\
\hline $0-5$ & 5 & 50 \\
$>5-10$ & 5 & 50 \\
\hline Jumlah & 10 & 100 \\
\hline
\end{tabular}

Sumber : Data Primer, 2015 (diolah)

Berdasarkan data dalam Tabel 12, sebanyak 50\% dari 10 suami yang membantu istri menghabiskan waktu sekitar 5 jam sehari. Waktu kerja suami lebih pendek dibandingkan waktu kerja istri, karena pekerjaan ini sebagian besar memang dikerjakan istri mulai dari membeli sayur, membersihkan hingga mendagangkannya. Sedangkan suami tidak terlibat dalam semua kegiatan proses pemasaran. Kegiatan yang sering melibatkan suami adalah saat proses pengangkutan di pagi hari. Dan sebanyak $50 \%$ suami yang membantu istri selama 10 jam sehari. Ini dikarenakan suami kebetulan 
tidak punya pekerjaan di luar rumah, sehingga waktunya lebih banyak digunakan untuk membantu istri dalam proses pembersihan sampai proses pemasaran sayuran.

\section{Pendapatan Anggota Keluarga dan Kontribusinya Terhadap Total Pendapatan Keluarga}

Total pendapatan keluarga didapat dari pendapatan setiap anggota keluarga yang terdiri dari pendapatan suami, istri, dan pendapatan anak yang sudah bekerja. Masingmasing anggota keluarga memegang peranan dalam peningkatan pendapatan guna perbaikan kesejahteraan keluarga. Pendapatan dari masing-masing anggota keluarga selanjutnya akan dijelaskan oleh tabel-tabel berikut ini.

Tabel 13 menunjukkan sebanyak 70\% memiliki pendapatan hingga Rp. 1.583.333 sebulan. Umumnya suami pada kelas ini bekerja sebagai buruh tani dan buruh bangunan dengan upah per hari Rp. 25.000 sampai Rp. 50.000. Pada kelas ini sudah termasuk suami yang tidak punya pekerjaan di luar rumah karena faktor usia dan faktor lainnya, tapi memiliki pendapatan yang didapat dari lamanya waktu membantu istri dalam proses penjualan sayur. Selanjunya suami dengan pendapatan lebih dari $\mathrm{Rp}$. 2.541.666 sebulan tercatat sebanyak 30\%. Tingginya pendapatan sebelumnya disebabkan oleh adanya dua sumber pendapatan suami yakni sebagai pegawai negeri dan wiraswasta.

Tabel 13. Distribusi Pendapatan Suami

\begin{tabular}{|c|c|c|}
\hline $\begin{array}{l}\text { Pendapatan } \\
\text { (Rp/Bulan) }\end{array}$ & $\begin{array}{l}\text { Jumlah } \\
\text { (Orang) }\end{array}$ & $\begin{array}{c}\text { Persentase } \\
(\%)\end{array}$ \\
\hline $\begin{array}{l}625.000- \\
1.583 .333\end{array}$ & 7 & 70 \\
\hline $\begin{array}{l}>1.583 .333- \\
2.541 .666\end{array}$ & 1 & 10 \\
\hline $\begin{aligned}> & 2.541 .666- \\
& 3.500 .000\end{aligned}$ & 2 & 20 \\
\hline Jumlah & 10 & 100 \\
\hline
\end{tabular}

Sumber : Data Primer, 2015 (diolah)
Tabel 14. Distribusi Pendapatan Anak

\begin{tabular}{ccc}
\hline $\begin{array}{c}\text { Pendapatan } \\
\text { (Rp/Bulan) }\end{array}$ & $\begin{array}{c}\text { Jumlah } \\
\text { (Orang) }\end{array}$ & $\begin{array}{c}\text { Persentase } \\
(\%)\end{array}$ \\
\hline $0-500.000$ & 5 & 50 \\
$>500.000-$ & 3 & 30 \\
1.000 .000 & & \\
$>1.000 .000-$ & 2 & 20 \\
1.500 .000 & & \\
\hline Jumlah & 10 & 100 \\
\hline
\end{tabular}

Sumber : Data Primer, 2015 (diolah)

Tabel 14 akan memperlihatkan distribusi pendapatan anak. Banyaknya anak yang tidak memiliki pendapatan seperti pada Tabel 14 sebanyak 50\%. Tidak adanya pendapatan dikarenakan mereka belum atau masih bersekolah dan sedang mencari pekerjaan.

Anak dengan pendapatan kurang dari Rp.1.000.000 sebulan hanya 30\%, yang didapat dari lamanya waktu membantu ibu dalam proses penjualan sayuran. Sisanya sebesar $20 \%$ memiliki pendapatan antara $\mathrm{Rp}$. 1.000.000 hingga Rp. 1.500 .000 sebulan, yang didapat dari pekerjaannya sebagai karyawan dan buruh bangunan.

Usia anak yang bekerja sudah pada usia produktif, yang bekerja sebagai karyawan setidaknya lulusan SMU; sedangkan anak yang pekerjaannya sebagai buruh berumur di atas 17 tahun.

Tabel 15. Responden Menurut Tingkat Pendapatan

\begin{tabular}{ccc}
\hline $\begin{array}{c}\text { Pendapatan } \\
\text { (Rp/Bulan) }\end{array}$ & $\begin{array}{c}\text { Jumlah } \\
\text { (Orang) }\end{array}$ & $\begin{array}{c}\text { Persentase } \\
(\%)\end{array}$ \\
\hline $1.102 .500-$ & 4 & 40 \\
2.052 .500 & & 60 \\
$>2.052 .500-$ & 6 & \\
3.002 .500 & & 100 \\
\hline Jumlah & 100 & \\
\hline
\end{tabular}

Sumber : Data Primer, 2015 (diolah)

Tabel 15 akan memperlihatkan distribusi pendapatan wanita sebagai pedagang sayuran. Berdasarkan data yang tersaji dalam Tabel 15 , sebanyak $40 \%$ yang memiliki pendapatan sebesar Rp. 1.102.500 
sampai Rp. 2.052.500 sebulan. Pendapatan di atas Rp. 2.052.500 sampai Rp. 3.002.500 sebulan tercatat sebanyak $60 \%$. Perbedaan pendapatan ini dipengaruhi oleh jumlah dan jenis dagangan dan harga jual. Semua responden tidak memiliki pendapatan diluar dari pekerjaan sebagai pedagang sayur karena mereka tidak memiliki pekerjaan sampingan.

Pendapatan responden diakuinya digunakan untuk keperluan rumah tangga mulai dari kebutuhan makan setiap hari, sekolah anak, tabungan arisan, sampai kebutuhan lainnya.

Tabel 16. Pendapatan Rata-rata Dan Kontribusi Terhadap Pendapatan Keluarga

\begin{tabular}{ccc}
\hline $\begin{array}{c}\text { Pendapatan } \\
\text { Anggota } \\
\text { Keluarga }\end{array}$ & $\begin{array}{c}\text { Pendapatan } \\
\text { Rata-rata } \\
\text { (Rp/ Bulan) }\end{array}$ & $\begin{array}{c}\text { Kontribusi } \\
(\%)\end{array}$ \\
\hline Suami & 1.487 .500 & 36,94 \\
Istri & 2.014 .000 & 50,01 \\
Anak & 525.000 & 13,03 \\
\hline Jumlah & 4.026 .500 & 100 \\
\hline
\end{tabular}

Sumber : Data Primer, 2015 (diolah)

Tabel 16 menunjukkan kontribusi suami lebih rendah yaitu $36,94 \%$ dari kontribusi istri sebesar 50,01\% . Bagi 10 wanita pedagang sayur, pendapatan rata-rata tersebut belum keseluruhan dari pendapatan yang diperoleh, karena masih ada jenis sayuran lain yang dijual oleh wanita pedagang sayur. Pendapatan suami dari pekerjaan membantu istri diperhitungkan sesuai dengan banyaknya jam kerja dalam proses penjualan sayuran.

Istri memiliki jam kerja lebih panjang dibandingkan suami, karena istri terlibat dalam semua kegiatan pemasaran mulai dari membeli sayur, membersihkan sayur hingga proses pemasaran sayuran.

Pekerjaan suami sebagai buruh diupah jauh di bawah rata-rata pendapatan istri. Pekerjaan inipun tidak dilakukan setiap hari dalam sebulan, sementara istri bisa mengatur sendiri hari kerjanya. Anak juga memegang peranan dalam perbaikan ekonomi keluarga meskipun kontribusi hanya $13,01 \%$. Selain pekerjaan yang didapat dari lamanya membantu ibu ada anak yang bekerja sebagai karyawan swasta dan buruh. Kecilnya kontribusi pendapatan anak disebabkan juga oleh upah yang kecil dan hari kerja yang tidak penuh dalam sebulan.

\section{KESIMPULAN DAN SARAN}

\section{Kesimpulan}

Bekerjanya ibu untuk mencari nafkah ternyata bukan sekedar untuk tambahan penghasilan tetapi merupakan sumber penghasilan keluarga disamping pendapatan suami dan anak. Kegiatan mencari nafkah di sektor informal yang dilakukan oleh para ibu yaitu dengan berdagang sayuran merupakan sumber pendapatan utama.

Pendapatan ibu rumah tangga yang berdagang di Pasar Pinasungkulan Karombasan Manado memberikan kontribusi terhadap pendapatan keluarga yaitu rata-rata sebesar 50,01\%. Artinya ibu memegang peranan penting dalam usaha meningkatkan pendapatan keluarga. Pendapatan ibu rumah tangga merupakan penghasilan utama dan ibu berperan sebagai pencari nafkah utama.

\section{Saran}

Usaha di sektor informal ini bisa dikembangkan lagi. Pendapatan yang di perolah selain untuk dikonsumsi sebaiknya digunakan juga sebagai tambahan modal usaha, sehingga usahanya dapat berkembang.

\section{DAFTAR PUSTAKA}

BKKBN. 1995. Pendidikan Kesejahteraan Keluarga. Jakarta : BKKBN.

Ihromi, T.O. 1990. Para Ibu yang Berperan Tunggal dan yang Berperan Ganda. Fakultas Ekonomi UI. Jakarta. 1995. Kajian Wanita Dalam Pembangunan. Fakultas Ekonomi UI. Jakarta.

Khairuddin, H. 2002. Sosiologi Keluarga. Yogyakarta : Liberty. 
Kuswardinah, Asih. 2007. Ilmu Kesejahteraan Keluarga. Semarang :

UNNES Press.

Mubyarto, 2004. Pengantar Ekonomi Pertanian. LP3ES Jakarta.

Mulyadi S. 2000. Ekonomi Sumber Daya Manusia Dalam Perspektif Pembangunan, PT. Raja Grafindo Persada, Jakarta.

Musrifah, 2009. Peranan Kepala Keluarga Wanita Di Pedesaan Dalam Upaya Memenuhi Kebutuhan Hidup Keluarga (Kasus 5 Janda Cerai Desa Sidorejo, Grobogan). Skripsi. Semarang: Fakultas Ilmu Pendidikan, Unnes.

Mongid, A. 1995. Gerakan Pembangunan Keluarga Sejahtera. Jakarta: BKKBN.

Oey-Gardiner, M. 1996. Perempuan Wanita Dalam Perkembangan Masyarakat Desa. CV. Rajawali. Jakarta.

Pudjiwati, Sayogyo. 1997. Peranan Wanita Dalam Perkembangan Masyarakat Desa. Jakarta : CV Rajawali.
Pujosuwarno, Sayekti. 1994. Bimbingan Dan Konseling Keluarga. Yogyakarta : Menara Mas Offset.

Sudarso, 1992. Pengantar Ekonomi Mikro. Penerbit Rineka Cipta, Jakarta.

Soekanto, Soerjono. 1992. Sosiologi Suatu Pengantar. Jakarta : CV. Rajawali. . 2002. Teori Peranan. Jakarta : Bumi Aksara. 2004. Sosiologi Keluarga (Tentang ikhwal keluarga, dan anak). Jakarta: CV. Rajawali.

Saefuddin, A.M., 1983. Pengkajian Pemasaran Komoditi. Dep. Ilmu-ilmu SosialEkonomi Fakultas Pertanian IPB. Bogor.

Suharjo, A dan Patong D., 2007. Usahatani. Institut Pertanian Bogor (IPB).

Soekartawi, 2003, Agribisnis Teori dan Aplikasi. PT Raya Grafindi Persada. 